Conference Article

\title{
Ion Nitriding of Titanium Alloys with a Hollow Cathode Effect Application
}

\author{
V.V. Budilov, K.N. Ramazanov, I.V. Zolotov, R.F. Khucnutdinov and S.V. Starovoitov
}

Ufa state aviation technical university, Ufa, Russia - 450008

Received 2 September 2015; Accepted 11 September 2015

\begin{abstract}
The method of ion nitriding the titanium VT6 alloy in glow discharge with the hollow cathode effect (HCE) was investigated. Probe measurements of glow discharge plasma under HCE conditions and without it were performed; ion densities near the cathode surface were measured. The effect of HCE on microstructure, microhardness and wear resistance of VT6 alloy was determined. The technology of ion nitriding titanium alloys, based on phase modification of the surface layer in glow discharge with HCE, was developed.
\end{abstract}

Keywords: surface hardening of titanium alloys, ion nitriding, glow discharge, hollow cathode effect, microhardness, wear resistance, VT6 titanium alloy.

\section{Introduction}

Due to the specific physical and mechanical properties of titanium alloys (heat resistance, high specific strength, high corrosion resistance, etc.), they are widely used in the manufacture of critical mechanical engineering parts [1].

However, application of titanium alloys is limited by their low resistance to abrasive and erosive wear, low hardness, low wear resistance. Therefore, it is important to develop new methods of titanium alloys surface hardening to improve the hardness and tribological properties of their surface [1-3].

Nowadays, an effective method for titanium alloys surface modification has been developed the thermochemical treatment, and more specific ion nitriding in gas discharges, which has high process speed at low process temperatures, and does not affect core material properties [1,4].

The ion nitriding processes based on HCE are difficult to develop as it is important to understand fully the physics of this phenomena and its influence on the substrate. Therefore, the investigation of ion nitriding in HCD plasma is a critical task, which will allow improving the resource-saving high technologies of surface hardening.

The aim of this work is to study the influence of hollow cathode effect (HCE) on discharge parameters, microstructure, microhardness and wear resistance of titanium alloy VT6 and develop the technology of surface hardening of titanium alloys.

* E-mail address:kamram@rambler.ru ISSN: 1791-2377 (C) 2015 Kavala Institute of Technology. All rights reserved.

\section{Methods of Study}

In order to study the effect of plasma parameters, a computer modeling of glow discharge with HCE plasma was performed. The discharge geometry consists of two disc electrodes, the cathode is covered with a disc mesh screen at a distance of $5 \mathrm{~mm}$. Calculations were carried out with a finite element technique modeling software .

For studying the characteristics of glow discharge plasma with HCE and without it, the probe method was used [5].

Nitriding of samples was carried out in the vacuum setup ELU-5 (Fig. 1). Samples of titanium alloy VT6 were nitrided in an atmosphere of argon and nitrogen (Ar-85\%, N2-15\%).

Surface microhardness values were measured with the microhardness tester Buehller Omnimet Micromet-1501 with a load of $0.5 \mathrm{~N}$. The optical microscope Olympus QX51 was used to obtain photos of microstructure.

Tribological tests were carried out on a Nanovea tribometer under a "ball on disk" load of $400 \mathrm{~g}$.

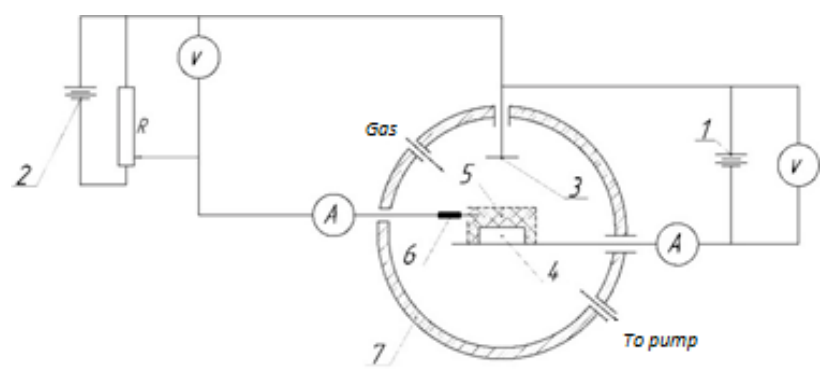

Fig. 1. Setup: 1 - discharge power source, 2 - probe power source, 3 - anode, 4 - cathode (sample), 5 - high density plasma, 6 - single cylindrical probe, 7 - vacuum chamber. 


\section{Results and Discussion}

Distribution of ion density in the cathode cavity, measured with the probe and calculated with modeling, are presented at Fig. 2.

The distributions have similar shape and order. Analysis of the obtained distribution shows that the maximum of ion density is located at center of the cathode cavity and equals $n_{i}=3.5 \cdot 10^{16} \mathrm{~m}^{-3}$. In discharge without HCE, the ion density at same distance from cathode surface was 1.5-2 times less. It is known [6], that an increase of ion density near the cathode surface leads to accelerating ions during the nitriding process.

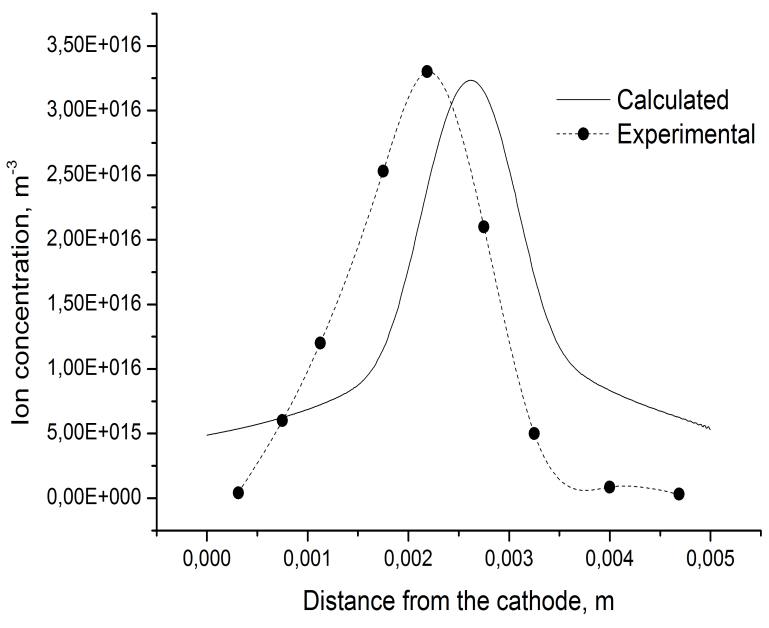

Fig. 2. Distribution of ion concentration in cathode cavity modeling (solid line) and probe measurements (dashed line).

Table. 1. Surface microhardness of nitride samples.

\begin{tabular}{|c|c|c|c|c|c|c|c|}
\hline \multirow[b]{2}{*}{$\begin{array}{l}\text { Nitriding } \\
\text { method }\end{array}$} & \multirow{2}{*}{$\begin{array}{c}\text { Before } \\
\text { treat- } \\
\text { ment } \\
\mathrm{H}_{\mathrm{V}} \mathrm{MPa}\end{array}$} & \multirow{2}{*}{$\begin{array}{c}\text { After } \\
\text { treatment } \\
\mathrm{H}_{\mathrm{v}} \mathrm{MPa}\end{array}$} & \multirow[b]{2}{*}{$\begin{array}{l}\text { Process } \\
\text { time } \tau, \mathrm{h}\end{array}$} & \multicolumn{4}{|c|}{ Process parameters } \\
\hline & & & & $\begin{array}{l}P, \\
\mathrm{~Pa}\end{array}$ & $\begin{array}{l}T, \\
{ }^{\circ} \mathrm{C}\end{array}$ & I, A & $\begin{array}{l}U, \\
\mathrm{~V}\end{array}$ \\
\hline $\begin{array}{c}\text { Without } \\
\text { HCE }\end{array}$ & \multirow{2}{*}{3570} & 14800 & \multirow{2}{*}{4} & 300 & \multirow{2}{*}{700} & 2 & \multirow{2}{*}{600} \\
\hline $\begin{array}{l}\text { With } \\
\text { HCE }\end{array}$ & & 9430 & & 90 & & 1,5 & \\
\hline
\end{tabular}

Results of microhardness measurements (Table. 1) show that nitriding in glow discharge with HCE increases surface microhardness up to 4 times, and conventional ion nitriding up to 2.6 times, when compared to the initial state of surface.

Microhardness increases due to the formation of titanium nitride on the material surface. Surface microhardness of nitrided with HCE sample is 1.6 times higher than that of conventional ion nitrided samples. This is linked to lower pressure [7] and increased ion concentration due to electrons oscillation.

Photos of microstructure of the samples nitrided with HCE and without it (Fig. 3).

In both cases solid, the nitride layer formed on the surface bonded well with the core. Nitrided sample were of gold color. The diffusion layer has a fine-grain structure; the transition from nitride layer to diffusion layer is smooth, which is one of the main requirements of the nitrided layer [4].

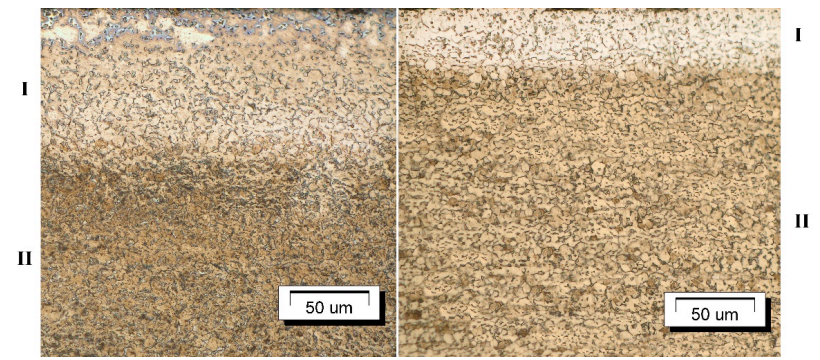

Fig. 3. Microstructure photos of VT6samples nitrided with HCE (a) and without it (b). I - nitride layer II - diffusion layer

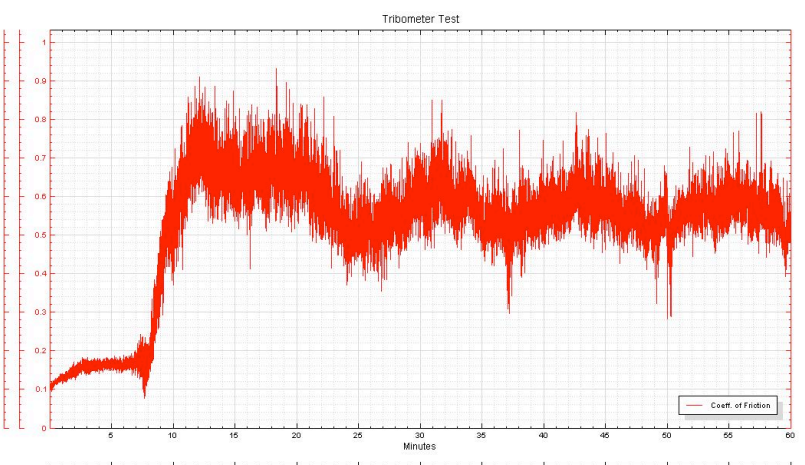

(a)

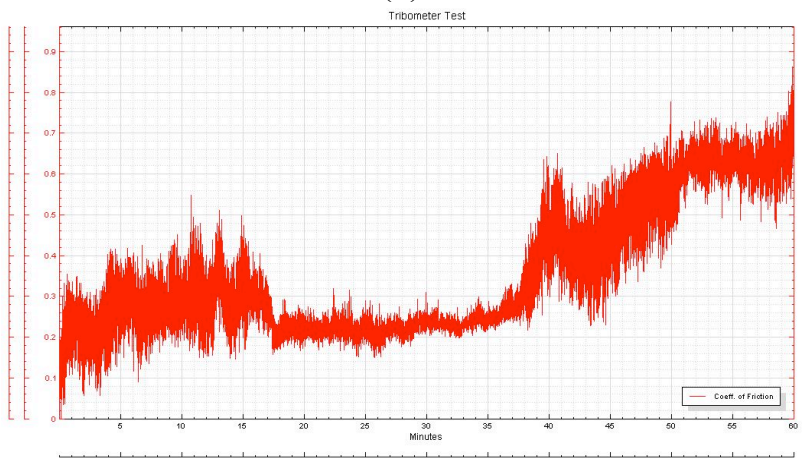

(b)

Fig. 4. Dependence of friction coefficient on wear ( $a$ - nitriding with HCE, $b$ - nitriding without HCE).

Analysis and comparison of the microstructure shows that the diffusion rate in HCE condition is several times higher than in conventional nitriding, at certain parameter values (temperature, process time).

Tribological properties were studied with a "ball on disk" setting. The dependences of friction coefficient on wear time for different surface areas of the sample is presented in Fig. 4.

The phase of unstable friction coefficient (bedding time) for a nitrided with HCE sample lasted for 17 minutes, and the coefficient of friction varied between 0.1 and 0.5 . Wear stage of nitride layer lasted for 20 minutes, for an average coefficient of friction of 0.25 . As a result of tribological tests it was established that application of HCE leads to decreasing the amount of worn material up to 4 times comparing to conventional ion nitriding in glow discharge.

Based on this work, the technology of ion nitriding with HCE was developed (Fig. 5).

The process temperature $\left(700^{\circ} \mathrm{C}\right)$ is lower than the polymorph transition temperature. Thus, the surface morphology does not change. At $600 \ldots 650^{\circ} \mathrm{C}$ a dissolution of the oxide film occurs and it leads to effective stress relief $[1,2]$. 


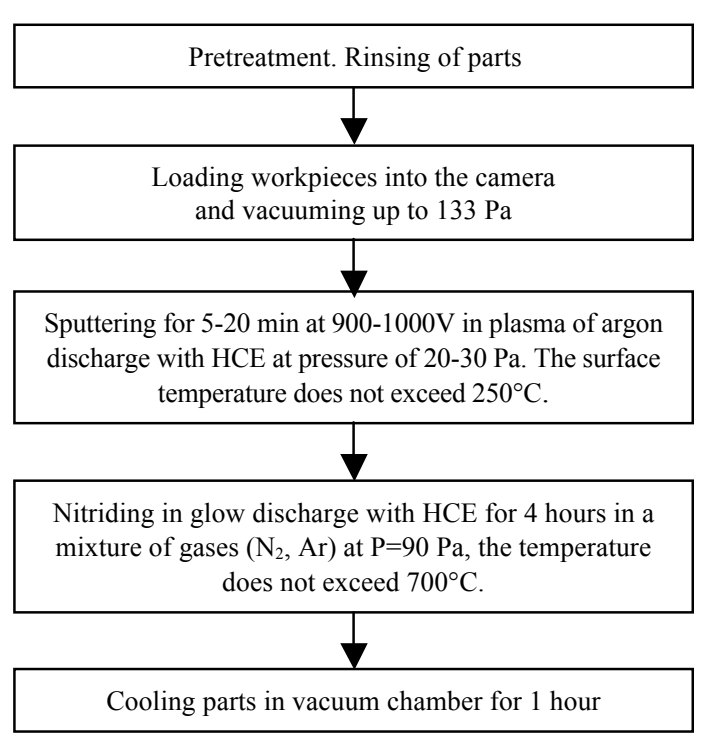

Fig. 5. Ion nitriding with HCE process

The developed technology of ion nitriding with HCE is an effective method of surface modification and provides high surface hardness and wear resistance of titanium alloys.

\section{Conclusions}

Computer modelling and probe measurements shows that HCE leads to an increase of ion density near the treated surface and intensifies the diffusion process.

Surface microhardness of VT6 samples increased 4 times after ion nitriding with $\mathrm{HCE}$, and 2.6 times with conventional ion nitriding. Increasing the microhardness occurs due to the formation of nitrides on treated surface.

The nitrided layer after ion nitriding with HCE consists of a nitride layer and a fine-grain diffusion zone. The transition from the nitride layer to the diffusion layer is smooth, which is one of the main requirements of the nitrided layer.

Samples of VT6 alloy after ion nitriding with HCE resist wear longer than samples processed by the conventional ion nitriding method at the same process temperature.

The technology for ion nitriding with HCE was developed. It is an effective method of surface hardening and improving the wear resistance of titanium alloys.

\section{References}

1. B.N. Arzamasov, A.G. Bratukhin, Yu.S. Eliseev, T.A. Panayoti, Ion thermos-chemical treatment of alloys, Moscow, MGTU im. Baumana, 1990. [in Russian]

2. L.S. Malinov, A.Sh. Zecheva, "Link of microstructure and properties of manufacturing titanium alloys with nitriding process parameters from gas phase", MiTOM, vol. 7, pp. 2128, 2004. [in Russian]

3. V.S. Mukhin, K.N. Ramazanov, D.Z. Ishmukhametov, "Hardening of surface of steels and titanium alloys by creating macroheterogeneous structure during nitriding in glow discharge", UTiP, vol. 10, pp, 32-35, 2010. [in Russian]

4. V.V. Budilov, R.D. Agzamov, K.N. Ramazanov, "Tecnology of ion nitriding in glow discharge with hollow cathode", MiTOM, vol. 7, pp. 25-29, 2007. [in Russian]

5. Yu.Kh. Akhmadeev, I.M. Goncharenko, Yu.F. Ivanov, N.N. Koval, P.M. Schanin, "Nitriding of pure titanium in glow discharge with hollow cathode", Pisma v ZhTF, vol. 13, no. 31, 2005. [in Russian]

6. V.G. Kaplun, N.S. Mashovets, "Dostizhennya vlastivrstey poverkhni titanovogo splavu VT8 pislya nizkotemperaturnogo azotuvannya $\mathrm{v}$ plasmi tliyuchugo rozryadu", Vestnik dvigatelestroeniya, vol. 2, pp. 190-193, 2008. [in Russian]

7. Yu.P. Raizer, Fizika gazovogo razryada, Moscow, Nauka, 1987. [in Russian] 